\title{
How does Business Orientation of Manufacturing Enterprises Define the Utilisation of Lean Production?
}

\section{Waleed Rashad ${ }^{1}$, Kornélia Lazányi ${ }^{2}$, Vojko Potocan ${ }^{3}$, Zlatko Nedelko ${ }^{3}$}

${ }^{1}$ University of Maribor, Faculty of Logistics, Mariborska 7, 3000 Celje, Slovenia, e-mail: waleed.rashad@redachem.com

${ }^{2}$ Keleti Károly Faculty of Business and Management, Óbuda University, Tavaszmező u. 17, 1084 Budapest, Hungary, e-mail: lazanyi.kornelia@kgk.uni-obuda.hu

${ }^{3}$ University of Maribor, Faculty of Economics and Business, Razlagova 14, 2000 Maribor, Slovenia, e-mail: vojko.potocan@um.si; zlatko.nedelko@um.si

\begin{abstract}
The main purpose of the research presented in this paper is the investigation of how lean production is applied and whether business orientation of manufacturing enterprises has any effect on lean production's utilisation. In order to determine the situation of lean production, the paper presents a multidisciplinary research framework consisting of manufacturing, management tools, and business orientation theories and analyses 224 responses of employees in the sampling areas of Western Europe, Central Europe, and Arabian Peninsula. The study indicates intensive utilisation of lean production in the responding enterprises, with its highest use in Central Europe, followed by Western Europe and on the last place the Arabian Peninsula. The analysis of business orientation revealed that: (1) internal orientation is strongest in Western Europe and weakest in Central Europe with small differences in strength of orientation and (2) external orientation is strongest in Western Europe and weakest on the Arabian Peninsula with significant differences between orientations of enterprises. Correlations of business orientation and lean productions' utilisation showed significant and positive impacts of: (1) internal enterprise orientation on lean production' utilisation among enterprises from Arabian Peninsula, and (2) external enterprise orientation among enterprises from Western Europe and from the Arabian Peninsula, while other relations were found to be neutral.
\end{abstract}

Keywords: lean; lean production; business orientation; internal orientation; external orientation; manufacturing enterprises 


\section{Introduction}

Since 1970s, the creation of the ideology of lean production, $[1,2]$ numerous approaches have emerged to improve enterprises' production to match the conditions of the globalised market. Promising improvement of the operations of enterprises has derived from the lean production concept, established through academic studies of Japanese manufacturing practices in the1970s [1, 3].

Early research of the lean concept was initiated in manufacturing, business, and logistic theories $[4,5]$. These theories established the basic foundations and models of utilisation of individual production solutions and lean philosophy in enterprises $[6,7]$. Business and management theories revealed how lean production contributes to costs reduction, quality improvement, utilisation of value chains, and flexibility of organisations $[8,9]$. Logistics theory established foundations for optimising flows in organisations, structural changes of the production's structure and interorganisational cooperation in production $[3,9]$.

Despite the comprehensive theoretical foundations of lean production $[1,7]$ literature remains fragmented in content and methodological conceptualisations of its: general definition $[6,10]$, measurement, and evaluation $[1,3]$, and suitability for the achievement of contradictory business goals $[4,5]$. In addition, the studies about relationships between situational factors and lean production utilisation uncover issues of applicability of lean production for the production of enterprises, which operate in specific economic conditions and under various circumstances [11, 12].

The present paper introduces a study on Lean production with the help of the answers of 224 employees from manufacturing enterprises in Central Europe, Western Europe, and the Arabian Peninsula. According to Holweg [3] recommendations on how to properly apply theories from different disciplines, authors modified the research tools of business, manufacturing, and management theories to fit the specific objectives of the present contribution and used them for the analysis of lean production.

To underline the significance and novelty of the research below, the present paper highlights and addresses four gaps of lean production's research that have been exposed in prior studies $[1,5]$. First, the authors study utilisation of lean production through multi-dimensional research, which includes heterogeneous production tools of enterprises and creates the bridge between the quite divided studies of manufacturing among scientific disciplines. Second, with consideration of business orientations, authors analyse the present orientation of enterprises and differences in enterprises' orientations among enterprises from several international areas. Third, following the studies about advantages and disadvantages of business orientations for enterprise, authors consider the direct causal effects of internal and external business orientation on utilisation of lean production among the researched enterprises. Finally, this study uncovers critical knowledge about specifics in lean 
production's utilisation among enterprises which operate under specific conditions and circumstances, as well as suggestions for future utilisation of lean production in the constantly changing global business environment.

\section{Theoretical Background and Hypotheses}

\subsection{Lean Production}

Lean production - also named Lean manufacturing, originated from the "Toyota production systems" and practices of Japanese manufacturing enterprises developed in the 1970s [13, 14]. The term "Lean production" was first used by Krafcik [10], and established through academics' and practitioners' studies in the 1990s [1, 9, $15]$.

Leading 'Lean' theorists - like Womack, et al. [14] and Shah and Ward [1], provide guidance for conceptual frameworks addressing the lean production's challenges in organisational practice. Initial lean studies investigated the foundations and essential models of Lean production through research of: its individual components [16], interrelationships of its components [3], the impact of organisational variables on lean [8], and lean implementation among manufacturing enterprises [2]. In addition, lean production theorists extended the lean philosophy and created the guiding principles underlying lean to an enterprise-level [2, 14, 15].

Reviewing the current lean literature indicates many understandings and definitions of "Lean production", which are mainly descriptive and have become very expansive over time $[4,9]$. The first conceptualizations of Lean production exposed its "practical perspective related to a set of management practices or techniques related to manufacturing" [1], while the newer ones expose its "philosophical perspective related to guiding principles and overarching goals of manufacturing" [3].

To avoid confusion concerning the available conceptualizations [9, 17] and traditions of lean theorists [3, 14], authors considered Lean production as an "integrated system that accomplishes production of goods/services with minimal buffering costs" [6].

\subsection{Utilisation of Tools and Lean Production}

During the last two decades' academics and practitioners expanded their study of lean production on several research areas and issues like: methodologies for measurement and validation [1], correlations between internal and external organisational factors and lean [2], lean's implementation in networked 
organisations [18], and relations between specific operating conditions and lean utilisation [5].

Several 'lean' theorists, such as Holweg [3] and Shah and Ward [1], share the idea that the selected methodological approach determines the possibility of measuring of lean production. Literature review reported that the lean idea - similarly to other enterprise frameworks, - can be conceptualized and studied as " a concept, a methodology, a method, a technique or a tool" [19]. Each of these appearance forms of lean production supports realisation of specific needs and demands of production on particular levels of business operations - i.e., from strategic to operational level $[3,20]$.

Following the implementation of tools analysing manufacturing [8, 9], authors study lean production as a tool and defined it as "an entity of processes, exercises, and analytical frameworks that supports utilisation and management of lean idea on the operational level of enterprises" [19]. This methodological approach enables comparison of the lean with other individual manufacturing tools - like Just in Time, and Total Quality Management [16], and various other frequently arising manufacturing tools $[5,19]$.

\subsection{Business Orientation and Lean Production}

In addition, analysis of correlations between specific conditions - caused by the environment and situational characteristics, in which enterprises operate, - and lean utilisation revealed diverse results [5, 19]. Thus, Lamming [8] reported about strong impact of globalised automotive productions on lean utilisation among enterprises from well developed countries; research of Buckley and Ghauri [18] indicate weak correlations between different designs of "agile supply chain" and lean utilisation; and Naylor, et al. [4] revealed that analysis of the isolated impact of lean in modern enterprises is not appropriate (and neither relevant) anymore, and suggest its inclusion in the analysis of integrated impact in series of production paradigms.

The present paper collaborates to the stream of these studies with the analysis of lean utilisation among enterprises from Western Europe, Central Europe, and the Arabian Peninsula. The interest for comparative research of lean among selected international areas is stemming from their fast-growing goods exchange, reciprocal co-operations, and a common participation in global supply chains $[18,21]$. In more details, interest for lean in enterprises from Western Europe accelerate their participation in the newest development initiatives - like Industry 4.0, application of new technologies and manufacturing solutions - like smart production, and needs for cost rationalization of operating $[2,17]$. Reasons for the growing use of lean among enterprises in Central Europe originate from their supply orientation, limited availability of natural resources, and their position as non-focal providers in international supply chains and companies $[2,22]$. Specific conditions for applying lean for enterprises from the Arabian Peninsula are the availability of oil and natural 
gas and lack of other resources (natural, economic, technological), logistical potentials of their location, and plan for fast development of the countries [23]. Hence, all three target groups of countries are increasingly interested in and intent on utilisation of lean production.

In spite of the common lean orientation among sampled enterprises, specifics of their operations - like business orientations, ways of inclusion in international cooperation, and conditions in which they operate - like availability of natural resources, level of development, ways for international cooperation of individual enterprises, caused the development of specific characteristics and different levels of utilisation of lean among them [2, 23]. The following hypotheses are formulated on the basis of these differences:

Hypothesis 1: Utilisation of lean production significantly differs across Western Europe, Central Europe, and Arabian Peninsula areas.

In last decades, studies about globalization [18], supply chains - as the dominant type of enterprises' cooperation in $2000 \mathrm{~s}$ [5], and multinational corporations (MNC) $[17,24]$, provoke interest for the analysis of relations between enterprises' business orientations and lean utilisation in enterprises [11, 12].

Scholars quoted several classifications of business orientations - from basic internal and external orientations to more sophisticated orientations, each of which expressed applied contentual and methodological starting points for enterprises' operations $[5,25]$. Irrespective of their variety, literature review of the known conceptualizations of orientations [26] revealed common presumptions about the importance of business orientation, existence of one prevailing orientation, and implementation of different streams of solutions for each orientation, among enterprises.

A detailed overview of the business orientation concept - together with its corresponding models, exceed the limitations of this research. Following the generally accepted basic presumptions about business orientation $[25,26]$ present paper focuses on the dichotomy of internal and external business orientations as variables of interests for the development of research hypotheses.

Following the traditions of business [25], management [9], and manufacturing [6, $15,22]$ theories authors defined internal business orientation of enterprises as "an approach to business that prioritizes the achievement of selected internal goals primarily profit, with high control of the overall costs and standards of quality in production and provision of services for customers". The meaning and content of internal orientation were developed over time $[25,26]$ from the maximisation of the profit with a product-centered view of the firm in the period before the 1970s [25], to the realisation of organisational profit with respect to customers' needs and demands through manufacturing and services in a globalised environment [5].

The review of literature about the operation of enterprises in globalised market environment $[18,21,24]$ leads to the definition of external business orientation as 
"an approach to business that prioritises identifying market changes and meeting the needs of customers, while maintaining high standards of quality and controlling the overall costs involved in the production of products and provision of services". Such orientation enables organisations to balance their internal focus of execution with their higher exposure and their engagement with the external environment of their operations $[2,5,15]$.

Since enterprises can apply internal or external business orientation in accordance with their goals and market conditions, academics and practitioners reported about the different selection of business orientation among individual manufacturing organisations $[7,25]$. Thus, present paper also focuses on the exploration of the below-listed hypothesis:

Hypothesis 2: Significant differences exist in business orientations among enterprises across Western Europe, Central Europe, and Arabian Peninsula areas.

Hypothesis 2a: Significant differences exist in internal business orientations of enterprises across Western Europe, Central Europe, and Arabian Peninsula areas.

Hypothesis 2b: Significant differences exist in external business orientations of enterprises across Western Europe, Central Europe, and Arabian Peninsula areas.

Regardless of the popularity of internal and external business orientations in enterprises $[15,25]$, literature shows no consensus about the advantages and disadvantages of these orientations regarding the enterprises' utilisation of lean productions $[15,24]$.

Academics and practitioners formulate large congruency about positive correlations between internal business orientation and lean utilisation of enterprises [6, 17, 27]. Internal business orientation accelerates the stream of lean activities, like minimization of costs and time of production, optimization of the performance of operations, and improvement of relations with customers [12]. The adaptability of lean production in various cultural $[2,23]$, economic $[2,8]$, and technological [9, 15] environments in which enterprises operated is less studied and explained.

Following the previous business and manufacturing studies [2, 3], we hypothesize that:

Hypothesis 3: Differences exist in the impact of internal orientation on lean production utilisation among manufacturing enterprises from Western Europe, Central Europe and Arabian Peninsula.

Concept of external business orientation has been widely used among researchers for explaining of lean production utilisation in global environment through studies of: impact of environment and situational factors on its utilisation $[5,25]$, relations of lean with individual business solutions [2,27], and impacts of lean utilisation on results of organisations and society [9, 18], among others. Another promising stream of studies revealed a series of contextual and situational' specifics which can affect the utilisation of lean in particular situations, like studies of lean utilisation in 
supply upstream in supply chains [7], the connection between lean and smart production [15], and lean utilisation in Industry 4.0 [12].

In line with the tradition of business and manufacturing theories [7, 16, 17], we hypothesize that:

Hypothesis 4: Differences exist in the impact of external orientation on lean production utilisation among manufacturing enterprises from Western Europe, Central Europe and the Arabian Peninsula.

\section{Methodology}

\subsection{Instrument}

For this survey, extensive research about knowledge, use, and satisfaction with management tools in organisations has been developed. International surveys for researching management tools in organisations [19, 20, 28, 29] have been utilized, while also new questions regarding 33 commonly used management tools in organisations have been added. The final version of the questionnaire consisted of three parts; Part 1 - which measures the basic demographic data of respondents and their organisations; Part 2 - which gathers general information about the use and knowledge about management tools in organisations; and Part 3 - which assesses knowledge about management tools, utilisation of management tools, and the satisfaction with the utilisation of management tools.

\subsection{Sample and Procedure}

The questionnaires were distributed in 2017 to the employees in manufacturing enterprises in Western Europe, Central Europe and the Arabian Peninsula via email. Based on a random sampling of enterprises, which had been determined for previous surveys of management tools $[20,28]$. During the research up to 3 direct email addresses of employees of the selected enterprises have been identified with the help of the enterprises' websites, to which the link of the survey has been sent. In each investigated geographical area 500 emails have been sent to employees, containing link a to the survey. The response rate for Western Europe was 14.2 percent, for Central Europe was 17.8 percent and for Arabian Peninsula 15.8 percent.

The sample for this paper included 71 respondents from Western Europe, 74 from Central Europe, and 79 from the Arabian Peninsula. All respondents were involved in manufacturing organizations. The characteristics of the sample $(n=224)$ are outlined in Table 1. 
Table 1

Demographic characteristics of respondents

\begin{tabular}{|lc|}
\hline Variables & $\begin{array}{c}\text { Aggregated } \\
\text { sample } \\
(\boldsymbol{n}=\mathbf{2 2 4})\end{array}$ \\
\hline Age & 39.25 \\
Work experience & 17.14 \\
Gender: Male & $70 \%$ \\
Female & $30 \%$ \\
Education: Finished high school & $25.4 \%$ \\
Bachelor's degree & $64.3 \%$ \\
Master's degree & $9.8 \%$ \\
PhD & $0.4 \%$ \\
Position: Professionals & $22.8 \%$ \\
First-line managers & $15.2 \%$ \\
Middle managers & $38.4 \%$ \\
Top managers & $23.6 \%$ \\
Brganizational size: Below 250 employees & $16.1 \%$ \\
More than 1 1000 employees & $64.3 \%$ \\
\hline
\end{tabular}

In present paper data from the first part of the survey, and data regarding utilisation of management tools from the third part of the questionnaire is introduced.

\subsection{Measures}

Demographic information such as education level was measured using scale items where respondents had options from "primary school" to "Ph.D.", for position from "professionals" to "top managers". For age, work experience, and organisational size respondents entered integer numbers regarding their age, work experiences and approximate number of employees in organisation. They also indicate their gender.

Management tools utilisation: respondents rated each of 33 management tools in the survey using a Likert-type scale ranging from "I always use" (1) to "I never use" management tool (7). Participants choose one answer for assessing each tool. Based on the exploratory factorial analysis, using varimax rotation and principal component extraction of 32 management tools, (since lean production is considered as a measurable variable), two latent variables have been created $(\mathrm{KMO}=.802$ indicate sampling is adequate and significant Bartlett's test of sphericity $(p<.001)$ justify utilisation of factor analysis [30]).

- Internal organisational orientation is represented accurately and in a reliable manner by the utilisation of eight management tools, namely benchmarking, core competencies, business process reengineering, knowledge management, balanced scorecard, total quality management, six sigma, and 
change management programs. The Cronbach's alpha coefficient for this scale is 0.769 .

- External enterprise orientation is represented accurately and in a reliable manner also by utilisation of eight management tools, namely customer relationship management, customer segmentation, outsourcing, supply chain management, satisfaction and loyalty management, mergers and acquisitions, and offshoring. The Cronbach's alpha coefficient for this scale is 0.718 .

\subsection{Research Approach}

As a first step elements of descriptive statistics and zero-ordered correlations between variables in the study for the aggregated sample have been outlined. In the second step, we used aone-way analysis of variance (ANOVA) in order to determine the current state of enterprise orientation and current level of lean production utilisation in Western Europe, Central Europe and Arabian Peninsula. As a third step hierarchical regression analysis has been used to determine the impact of internal and external enterprise orientation on lean production utilisation, while also controlling the impact of selected control variables, namely age, gender, education, position, and organisational size. We examined the impact of enterprise orientations on lean production utilisation, with two repetitions of hierarchical regression analysis, for both dependent variables to be entered in regression analysis.

For assessing normality, the Kolmogorov Smirnov test has been utilized, which revealed that the most variables of interest in the study do not markedly violate the assumptions of the normal distribution [31]. Additionally, the values for asymmetry and kurtosis for considered variables are ranged between $(-2 ; 2)$, which are acceptable in order to prove normal distribution [31,32].

Due to the single source of both the independent (i.e. lean production) and dependent variables (i.e. internal and external enterprise orientation) in one instrument, the possibility of bias exists [33]. We estimated the common method variance utilizing an exploratory factor analysis in SPSS. We loaded all 33 management tools onto a single factor and constrained so that there was no rotation [33]. The newly introduced common latent factor explains 22.667 percent of the variance, indicating that the possible presence of common method bias is below the threshold value of $50 \%$ [34].

Regarding multi-collinearity, collinearity statistics for conducted hierarchical regression analyses were calculated [31]. Tolerance values are greater than 0.10 and VIF values are way below 10, which are acceptable [30] and indicate that multicollinearity is not an issue in this survey. 


\section{Results}

Table 2 presents the mean values, standard deviations, and zero-ordered correlations among variables in the research for the aggregated sample.

Table 2

Means, standard deviations and zero-ordered correlations among variables in the research for aggregated sample

\begin{tabular}{|c|c|c|c|c|c|c|c|c|c|c|}
\hline Variable $^{\mathrm{a}}$ & $\mathbf{M}$ & SD & 1 & 2 & 3 & 4 & 5 & 6 & 7 & 8 \\
\hline 1.Age & $\begin{array}{l}39.2 \\
5\end{array}$ & 8.19 & 1 & & & & & & & \\
\hline 2.Gender & 1.30 & .46 & -.07 & 1 & & & & & & \\
\hline 3.Education & 2.85 & .60 & $-.16^{*}$ & -.11 & 1 & & & & & \\
\hline 4.Position & 2.67 & 1.17 & $.54 * * *$ & -.08 & .08 & 1 & & & & \\
\hline $\begin{array}{l}\text { 5.Organisat } \\
\text { ional size }\end{array}$ & 4.01 & .68 & -.04 & -.00 & $.28 * * *$ & -.12 & 1 & & & \\
\hline 6.Region & 2.04 & .94 & -.09 & $-.28 * * *$ & -.07 & -.12 & .13 & 1 & & \\
\hline $\begin{array}{l}\text { 7.Lean } \\
\text { production }\end{array}$ & 4.54 & 2.09 & $-.29 * * *$ & $k^{-}-.12$ & .02 & $-.29 * * *$ & -.12 & $.27 * * *$ & 1 & \\
\hline $\begin{array}{l}\text { 8.Internal } \\
\text { enterprise } \\
\text { orientation }\end{array}$ & 5.70 & .94 & $-.28 * * *$ & ${ }^{k} .10$ & $-.26^{* * *}$ & $-.35^{* * *}$ & $-.18^{* *}$ & .03 & $.34 * * *$ & 1 \\
\hline $\begin{array}{l}\text { 9.External } \\
\text { enterprise } \\
\text { orientation }\end{array}$ & 4.38 & .94 & $-.31^{* * *}$ & .00 & $-.15^{* *}$ & $-.39 * * *$ & $-.21 * *$ & $.23^{* *}$ & $.51 * * *$ & $.48 * * *$ \\
\hline
\end{tabular}

${ }^{a} N=224 ; * p<.05, * * p<.01, * * * p<.001$

According to the above table several associations are noteworthy. First, there are associations between lean production and internal enterprises' orientation and $(\mathrm{r}=.34, p<.001)$ and between lean production and external enterprises' orientation $(\mathrm{r}=.51, p<.001)$, which provides fertile ground for discussion about the impact of lean production on enterprises' orientation. Second, region is correlated with usage of lean production $(\mathrm{r}=.27, p<.001)$ and external enterprises' orientation $(\mathrm{r}=.23$, $p<.05)$, indicating that differences exists regarding lean production utilisation and external enterprises' orientation between organisations from different observed regions. In Table 3 we present utilisation of lean production and enterprises' orientation in Western Europe, Central Europe, and the Arabian Peninsula. 
Table 3

Lean production utilisation and enterprises' orientation in Western Europe, Central Europe and Arabian Peninsula

\begin{tabular}{|c|c|c|c|c|c|c|c|}
\hline \multirow[t]{2}{*}{ Variables $^{a}$} & \multicolumn{2}{|c|}{ Western Europe } & \multicolumn{2}{|c|}{ Central Europe } & \multicolumn{2}{|c|}{$\begin{array}{l}\text { Arabian } \\
\text { Peninsula }\end{array}$} & \multirow[t]{2}{*}{$\mathbf{F}$} \\
\hline & Mean & SD & Mean & SD & Mean & SD & \\
\hline Lean production & 4.17 & 2.13 & 3.85 & 1.70 & 5.52 & 2.04 & $15.62 * * *$ \\
\hline $\begin{array}{l}\text { Internal } \\
\text { enterprises' } \\
\text { orientation }\end{array}$ & 5.63 & .97 & 5.79 & .61 & 5.69 & 1.15 & .55 \\
\hline $\begin{array}{l}\text { External } \\
\text { enterprises' } \\
\text { orientation }\end{array}$ & 4.13 & .92 & 4.33 & .81 & 4.66 & 1.01 & $6.31 * *$ \\
\hline
\end{tabular}

${ }^{a} N=224 ; * p<.05, * * p<.01, * * * p<.001$

The above results reveal significant differences in utilisation of lean production across Western Europe, Central Europe, and the Arabian Peninsula, where lean production has the highest use in Central Europe, followed by Western Europe, while it is at least used in the Arabian Peninsula. This confirms Hypothesis 1.

Turning to the state of enterprise orientation it is evident that internal enterprise orientation is the strongest in Western Europe, tightly followed by the Arabian Peninsula and Central Europe, revealing no significant differences among compared areas. This suggests rejection of Hypothesis 2a. Oppositely, regarding external orientation, there are significant differences, where external enterprise orientation is strongest in Western Europe and the weakest at the Arabian Peninsula. This supports Hypothesis $2 b$.

Next, we outline the results of hierarchical regression analysis, where the impact of internal enterprise orientation (see Table 4) and external enterprise orientation (see Table 5) on lean production utilisation across Western Europe, Central Europe, and the Arabian Peninsula is explored.

Table 4

Hierarchical regression analysis of internal enterprises' orientation on lean production utilisation in Western Europe, Central Europe and the Arabian Peninsula

\begin{tabular}{lcccccc}
\hline Variables & \multicolumn{2}{c}{ Western Europe } & \multicolumn{2}{c}{ Central Europe } & \multicolumn{2}{c}{ Arabian Peninsula } \\
\cline { 2 - 7 } & Model 1 & Model 2 & Model 1 & Model 2 & Model 1 & Model 2 \\
\hline Block 1: Controls & & & & & & \\
Age & $-.51^{* *}$ & $-.49 *$ & .08 & .10 & -.06 & .04 \\
Gender & -.10 & -.09 & .02 & .01 & -.13 & -.14 \\
Education & .19 & .20 & -.02 & -.02 & -.09 & -.01 \\
Position & .01 & .02 & $-.29 *$ & $-.27 *$ & -.14 & .00 \\
$\begin{array}{l}\text { Organisational } \\
\text { size }\end{array}$ & -.09 & -.08 & -.16 & -.19 & $-.42 * * *$ & $-.24 *$
\end{tabular}


Block 2

\begin{tabular}{|c|c|c|c|c|c|c|}
\hline $\begin{array}{l}\text { Internal enterprise } \\
\text { orientation }\end{array}$ & & .03 & & .11 & & $.54 * * *$ \\
\hline$n$ & 71 & 71 & 74 & 74 & 79 & 79 \\
\hline $\mathrm{R}^{2}$ & .18 & .18 & .11 & .12 & .26 & .44 \\
\hline Model F & $2.83^{*}$ & $2.33^{*}$ & 1.66 & 1.51 & $4.95^{* *}$ & $9.41 * * *$ \\
\hline
\end{tabular}

${ }^{a} N=224 ; * p<.05, * * p<.01, * * * p<.001$

The above table reveals that internal enterprise orientation is significantly and positively correlated with utilisation of lean production in the Arabian Peninsula, while there is no significant association for Western Europe and Central Europe. This supports hypothesis 3 .

Parallel to this the below table reveals that external enterprises' orientation is significantly and positively correlated with utilisation of lean production in Western Europe and the Arabian Peninsula, while there is no significant association for Central Europe. This supports hypothesis 4.

Table 5

Hierarchical regression analysis of external enterprises' orientation on lean production utilisation in Western Europe, Central Europe and Arabian Peninsula

\begin{tabular}{|c|c|c|c|c|c|c|}
\hline \multirow[t]{2}{*}{ Variables } & \multicolumn{2}{|c|}{ Western Europe } & \multicolumn{2}{|c|}{ Central Europe } & \multicolumn{2}{|c|}{ Arabian Peninsula } \\
\hline & Model 1 & Model 2 & Model 1 & Model 2 & Model 1 & Model 2 \\
\hline \multicolumn{7}{|c|}{ Block 1: Controls } \\
\hline Age & $-.51 * *$ & -.14 & .08 & .06 & -.06 & .06 \\
\hline Gender & -.10 & -.13 & .02 & .02 & -.13 & -.10 \\
\hline Education & .19 & .07 & -.02 & -.02 & -.09 & -.01 \\
\hline Position & .01 & .07 & $-.29 *$ & -.23 & -.14 & -.08 \\
\hline $\begin{array}{l}\text { Organisational } \\
\text { size }\end{array}$ & -.09 & .11 & -.16 & .14 & $-.42 * * *$ & $-.31 * *$ \\
\hline \multicolumn{7}{|l|}{ Block 2} \\
\hline $\begin{array}{l}\text { External } \\
\text { enterprise } \\
\text { orientation }\end{array}$ & & $.66^{* * *}$ & & .19 & & $.36^{* *}$ \\
\hline$n$ & 71 & 71 & 74 & 74 & 79 & 79 \\
\hline $\mathrm{R}^{2}$ & .18 & .44 & .11 & .14 & .26 & .33 \\
\hline Model F & $2.83^{*}$ & $8.33 * * *$ & 1.66 & 1.80 & $4.95 * *$ & $5.87 * * *$ \\
\hline
\end{tabular}

${ }^{a} N=224 ; * p<.05, * * p<.01, * * * p<.001$ 


\section{Discussion}

The main purpose of the present paper was to examine the impact of enterprise orientation on lean production utilisation in Western Europe, Central Europe, and the Arabian Peninsula. Results outlined many possible focal points for discussion. Here, we are highlighting several most notable.

Turning first to the utilisation of lean production in enterprises, there is a significantly higher level of lean production utilisation in enterprises in Central Europe, than in other two observed regions, stemming from the fact that enterprises in Central Europe are mainly acting as suppliers, where there is a strong emphasis on the improvement of their processes in order to be competitive and comply with the requirements of focal organisations [28]. Focal organisations often also provide standard operating procedures in order to ensure quality and to strive toward cost minimization, which is reflected also in the relatively high importance of lean production in Western Europe. Turning to the Arabian Peninsula it is typical that the main source of income is generated from the oil \& gas industry, the enterprises in this region are not strongly committed to the utilisation of lean production, such as in Central Europe for example. The constant strong demand for oil \& gas does not push the enterprises in this area to put lean production in the focus. The nature of competition in oil \& gas is different than in other industries - such as the automotive - which requires the mandatory implementation of lean principles [23, 35]. This implies low interest in lean production implementation in organisations in this area.

Regarding enterprise orientation, enterprises in all three considered areas put external over internal enterprise orientation in the forefront. This reflects the current trend in the world economy, which is emphasizing the prevalence of tight collaboration between organisations in the frame of supply chains, going beyond focusing solely on the enterprises' goals [15]. As outlined, the high external enterprise orientation of Western Europe is expected since organisations put the concern for their customers in the forefront [36], as well as they are having a plethora of relations with their suppliers, due to organisational focus on core activities [28]. Due to tight collaboration with suppliers, our results also confirm high external enterprise orientation in Central European organisations, where a plethora of enterprises are acting as first/second-tier suppliers to the large supply chains, often controlled by Western economics. The high external orientation of organisations from Central Europe is in accordance with their high level of outsourcing in former post-transition economies from Central Europe, as well as linkages with Western supply chains (e.g. automotive industry) $[28,36]$. Turning to the Arabian Peninsula area, external enterprise orientation is more prevalent over internal; and it is reflecting the need for collaboration with organisations around the Globe. In this area, organisations mainly depend on sourcing the raw materials worldwide, while the percentage of the local components is minor. The main exception is the petroleum and petrochemicals industry, where the majority of the 
raw materials exist locally. This trend of international sourcing made it necessary to enhance the collaboration with the supply chain partners worldwide which is also reflected in the external orientation of the organisations and the usage of outsourcing as a management tool [29].

Following the results regarding the impact of enterprise orientation on lean production utilisation across examined regions, we can outline following: In Western Europe enterprises usually focus on their core activities, while other activities are outsourced to the areas where labour costs are lower, ranging from Central and East Europe to Asia. This implies, that Western organisations provide very detailed standardized operating procedures, requirements for quality, efficiency of processes, etc. in order to ensure adequate quality, as well as to keep their costs low. These actions reflect key elements of lean production like standardized processes, total quality management programs, just in time, and the efficiency of processes [27]. This implies that in Western European enterprises less focus is needed on lean production, which is a primary concern of the supplier. Thus, Western European enterprises put in the forefront the focus on customers [28, 36]. These cognitions reflect significant impact of external enterprise orientation on lean production utilisation and non-significant impact of internal enterprise orientation on lean production utilisation of Western Europe enterprises.

For Central Europe, it is evident that there is no significant impact of both enterprise orientations on lean production utilisation. This may be a consequence of several factors. First, enterprises are the members of the supply chain(s), where they are following standardized operating procedures and rules provided by focal enterprises, which is confirmed by the findings that outsourcing is most commonly used and recognized management tools in Slovenia and in Croatia, as examples of Central Europe economies [28, 36]. Second, the role and the importance of lean production is not well recognized in organisations in this area, although our results emphasize relatively high utilisation of lean production, compared to the Western European and Arabian Peninsula sample. In international studies exploring management tools in that part of Europe, lean production is not among the top ten used tools [28]. Thus, high utilisation is often the consequence of following guidelines from Western economies, acting as a focal enterprise in the supply chain, which focuses on ensuring high quality and low costs. Third, enterprises in Central Europe are often criticized for their lack of long-term orientation and clear future strategy, which will put strategic management at the forefront of the enterprises interest [28]. Finally, there are also several post-transition problems, like dispersed ownership, unfinished privatization, which can have an influence on the current state. Consequently, lean production utilisation is currently used as a necessary tool when collaborating with supply chain partners and is used especially for improving enterprise operations, while the association with enterprises orientation is neither recognized nor established in this part of Europe yet.

Turning to the Arabian Peninsula it is evident that both, internal and external enterprise orientations support lean production. Higher-level external enterprise 
orientation is associated with high level of lean production utilisation, which reveals that the enterprises in this area recognize their position in the extended supply chain clearly. The reasons for this are mainly the following: First, the utilisation of lean production requires basically an active search for the best raw materials within the best cost $[13,14]$. This needs strong connections externally with a group of suppliers upstream of the supply chain. Second, downstream the supply chain with the customers, the organisations also need strong connections to have high visibility of the demand. This certainty and predictability of demand is one of the main elements for lean production utilisation. Third, the internal enterprise goals are connected and contributing to the supply chain goals, so the internal orientation is utilized to support the orientation of the entire supply chain. This orientation internally or across the supply chain - is very obvious in the Arabian Peninsula area due to the special characteristics of the enterprises in this area, like (1) the major portion of the business is related to oil $\&$ gas and petrochemicals industries, where not many alternative sources are available since due to the very technical nature of these industries, the number of reliable suppliers is always restricted; (2) with a limited number of reliable suppliers, and specific group of customers, the supply chain orientation must be high to support the portfolio; and (3) the internal orientation is used with a clear goal of contributing to the supply chain orientation.

Another obvious direction for the discussion, when lean production utilisation is in the centre of attention, is also its relatedness to the Industry 4.0 implementation. Lean production is considered an important building block of digitalization of organisations $[12,15]$. Comparing obtained mean values of lean production utilisation with results of surveys using same scale and instrument for examining management tools utilisation [28, 29, 36], reveals that lean production is not among top ten used management tools in Central Europe, when considering several tools, implying relative low readiness for industry 4.0 implementation.

\section{Conclusions}

Based on our findings we can state that enterprises showed strong external as well as strong internal orientation, which is contrary to the traditional trade-off between optimization of internal enterprise processes vs. optimization of the entire supply chain [37]. This implies that enterprises have overcome the need for this trade-off [26]. What is even more striking, external enterprise orientation surpasses internal enterprise orientation, which had been on the pedestal for decades. We can further argue that enterprises from Western Europe are exposed the strongest to external enterprise orientation, which is reflected in their status as a focal company [26], around which the supply chain is built. Central European enterprises also emphasize the importance of external orientation, but their emphasis is lower than that in Western European enterprises. One can conclude that in both regions, enterprises put their external-i.e. supply chain orientation - in the forefront. This may reflect that enterprises from Central Europe; (1) are not solely bonded to one but several supply chains; (2) act also as focal enterprises in other supply chains; or (3) have 
not yet developed and reached such levels of supply chain orientation as enterprises in Western Europe.

In terms of theoretical contributions, the paper first introduced two facets of enterprise orientations, building upon theoretical framework about relations of organisations in supply chains [37]. The study determined internal and external enterprise orientation based on the utilisation of commonly used management tools in enterprises [28, 29, 36]. Further, the paper provided empirical verification and further theoretical development of the model of linkages between enterprises in supply chains [37]. Second, the linkages between enterprises' orientation and utilisation of lean production were established and empirically verified across three regions, which will be helpful for further examination and discussion of lean production utilisation as well as about readiness of enterprises for digitalization.

Among practical implications, the most significant are the following: First, knowing the actual state of lean production utilisation is beneficial for the management of the enterprises since the implementation of lean manufacturing is a strategic decision [35]. With our survey's results, the managers get an insight into the current state of lean production utilisation, which provides a fertile ground for designing actions to increase the level of lean production utilisation. This will be helpful to improve the enterprise's performance, follow developmental trends, and adhere to the requirements of business partners. Multinationals may also benefit from the results since the actual state of lean production utilisation is revealed. Second, based on the presumption that lean production is a "cornerstone" for implementation of industry 4.0 principles $[15,22]$ and that wide adoption of Industry 4.0 practices will be easier if lean production practices are highly used in organisations [12], we can state to be able to influence the success and pace of industry 4.0 implementation in enterprises through utilisation of lean production. Third, from the supply chain management perspective, enterprises need to balance their strategy between focusing on internal optimization and focus on the entire supply chain [26, 37]. Thus, knowing the actual state of the enterprise orientation is helpful for enterprises to adopt further steps toward desired orientation, according to the needs of the enterprise.

The authors are aware of the present study's limitations. First, and foremost bias is prevalent since the actual level of management tools utilisation might be different from the assessed, while some of the respondents may not be completely familiar with the usage of every single tool in other departments in their enterprise. Second, the focus on three regions may limit broader generalization of the findings, due to the possible differences in management tools utilisation within the regions [28], as well as utilisation of management tools among countries [29]. For instance, specifics in post-transitional economies in Central Europe, like Slovenia, Hungary, Slovakia, etc. [36, 37] may hinder broader generalization. Third, with utilisation of regression analysis we examined the impact of enterprise' orientation on lean production utilisation, separately for internal and external orientation. This may have some implications on the results since the impact of both orientations is not 
simultaneously considered. In addition, we do not distinguish between focal organisation and other participants in the supply chain, rather we are interested in orientation of each of the enterprises in supply chain [38].

Results and findings of present study outline future research directions. Our aim is first to follow the definition of business orientation [38], which in frame of external business orientation distinguishes between supplier and customer orientation. This study can be upgraded in a way, where external orientation will be considered as supplier and customer orientation [39]. This will more precisely explain external organisation orientation, due to the differences across regions regarding focusing on customers, suppliers and internal processes [29, 36]. Due to the significant effect of several control variables, (namely age in Western Europe, position in Central Europe and organisational size in Arabian Peninsula) on lean production utilisation, it would be beneficial to further examine the role of these variables. Linkages between lean production utilisation and industry 4.0 practices utilisation should also be further investigated, in order to support theoretical assumptions $[15,22]$. In addition to this, it would be beneficial to know, how definite management tools are used in enterprises, and are related to the enterprise's internal and external orientation [40]. This will reveal which management tools support, and which hinder each orientation.

\section{Acknowledgement}

The paper has been financed from the 2018-2.1.11-TÉT-SI-2018-00013 grant sponsored by the National Research, Development and Innovation Office.

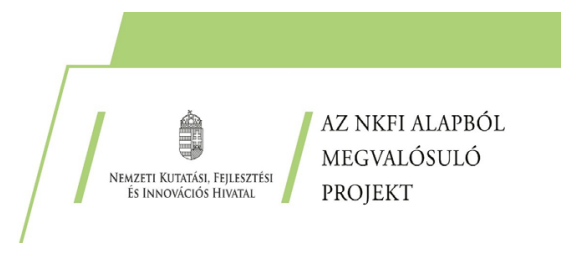

\section{References}

[1] R. Shah and P. T. Ward, "Defining and developing measures of lean production," Journal of Operations Management, Vol. 25, No. 4, pp. 785$805,2007 / 06 / 01 / 2007$

[2] G. Herrigel, "Globalization and the German industrial production model," Journal for Labour Market Research, Article Vol. 48, No. 2, pp. 133-149, 2015

[3] M. Holweg, "The genealogy of lean production," Journal of Operations Management, Vol. 25, No. 2, pp. 420-437, 2007/03/01/ 2007

[4] B. J. Naylor, M. M. Naim, and D. Berry, "Leagility: Integrating the lean and agile manufacturing paradigms in the total supply chain," International Journal of Production Economics, Vol. 62, No. 1-2, pp. 107-118, 1999 
[5] A. E. Staedele, S. R. Ensslin, and F. A. Forcellini, "Knowledge building about performance evaluation in lean production: An investigation on international scientific research," Journal of Manufacturing Technology Management, Review Vol. 30, No. 5, pp. 798-820, 2019

[6] W. Hopp and M. Spearman, "To Pull or Not to Pull: What Is the Question?," Manufacturing and Service Operations Management, Vol. 6, No. 2, pp. 133148,2004

[7] N. V. K. Jasti and R. Kodali, "Lean production: literature review and trends," International Journal of Production Research, Vol. 53, No. 3, pp. 867-885, 2015/02/01 2015

[8] R. Lamming, "Squaring lean supply with supply chain management," International Journal of Operations and Production Management, Review Vol. 16, No. 2, pp. 183-196, 1996

[9] J. Pettersen, "Defining lean production: Some conceptual and practical issues," TQM Journal, Article Vol. 21, No. 2, pp. 127-142, 2009

[10] J. F. Krafcik, "Triumph of the lean production system," (in English) Sloan Management Review, Article Vol. 30, No. 1, pp. 41-51, Fal 1988

[11] Behun, M., Gavurova, B., Tkacova, A., Kotaskova, A. (2018) The impact of the manufacturing industry on the economic cycle of European Union countries. Journal of Competitiveness, 10(1): 23-39, doi: $10.7441 /$ joc. 2018.01 .02

[12] M. Rossini, F. Costa, G. L. Tortorella, and A. J. T. I. J. o. A. M. T. PortioliStaudacher, "The interrelation between Industry 4.0 and lean production: an empirical study on European manufacturers," journal article Vol. 102, No. 9, pp. 3963-3976, June 012019

[13] T. Ohno, Toyota Production System: Beyond Large Scale Production. Cambridge, MA: Productivity Press, 1988

[14] J. Womack, D. Jones, and D. Roos, The Machine That Changed the World. New York: Free Press, 1990

[15] S.-V. Buer, J. O. Strandhagen, and F. T. S. Chan, "The link between Industry 4.0 and lean manufacturing: mapping current research and establishing a research agenda," International Journal of Production Research, Vol. 56, No. 8, pp. 2924-2940, 2018/04/18 2018

[16] J. J. Dahlgaard and S. M. Dahlgaard-Park, "Lean production, six sigma quality, TQM and company culture," TQM Magazine, Article Vol. 18, No. 3, pp. 263-281, 2006

[17] F. Ciccullo, M. Pero, M. Caridi, J. Gosling, and L. Purvis, "Integrating the environmental and social sustainability pillars into the lean and agile supply chain management paradigms: A literature review and future research 
directions," Journal of Cleaner Production, Vol. 172, pp. 2336-2350, 2018/01/20/ 2018

[18] P. J. Buckley and P. N. J. J. o. I. B. S. Ghauri, "Globalisation, economic geography and the strategy of multinational enterprises," journal article Vol. 35, No. 2, pp. 81-98, March 012004

[19] V. Potocan, Z. Nedelko, and M. Mulej, "Influence of Organisational Factors on Management Tools Usage in Slovenian Organisations," Inzinerine Ekonomika-Engineering Economics, Vol. 23, No. 3, pp. 291-300, 2012

[20] V. Potocan and Z. Nedelko, Supply chain management and management tools. Harlow: Pearson Education, 2017

[21] I. Filatotchev, A. Poulsen, and R. G. Bell, "Corporate governance of a multinational enterprise: Firm, industry and institutional perspectives," Journal of Corporate Finance, Vol. 57, pp. 1-8, 2019/08/01/2019

[22] H. Bauer, F. Brandl, C. Lock, and G. Reinhart, "Integration of Industrie 4.0 in Lean Manufacturing Learning Factories," Procedia Manufacturing, Vol. 23, pp. 147-152, 2018/01/01/2018

[23] G. Sarhan, B. Xia, S. Fawzia, and A. Karim, "Lean construction implementation in the Saudi Arabian construction industry," Construction Economics and Building, Vol. 17, No. 1, pp. 46-69, 2017

[24] J. R. Markusen, "The Boundaries of Multinational Enterprises and the Theory of International Trade," The Journal of Economic Perspectives, Vol. 9, No. 2, pp. 169-189, 1995

[25] I. Lings, "Balancing internal and external market orientations," Journal of Marketing Management, Vol. 15, No. 4, pp. 239-263, 1999

[26] T. Esper, C. Defee, and J. Mentzer, "A framework of supply chain orientation," The International Journal of Logistics Management, Vol. 21, No. 2, pp. 161-179, 2010

[27] V. Kannan and K. Tan, "Just in time, Total quality management, and Supply chain management: Understanding their linkages and impact on business performance," OMEGA: The International Journal of Management Science, Vol. 33, No. 2, pp. 153-162, 2005

[28] M. Dabic, V. Potocan, Z. Nedelko, and T. R. Morgan, "Exploring the use of 25 leading business practices in transitioning market supply chains," International Journal of Physical Distribution \& Logistics Management, Vol. 43, No. 10, pp. 833-851, 20132013

[29] D. K. Rigby and B. Bilodeau, "Management Tools \& Trends 2015," 2015

[30] J. F. Hair, R. E. Anderson, R. L. Tatham, and W. C. Black, Multivariate Data Analysis with Readings. Englewood Cliffs, NJ: Prentice-Hall, 1998 
[31] R. Ho, Handbook of Univariate and Multivariate Data Analysis and Interpretation with SPSS. Boca Raton, FL: Chapman \& Hall/CRC, 2006

[32] D. George and M. Mallery, SPSS for Windows Step by Step: A Simple Guide and Reference, 17.0 update. Boston: Pearson, 2010

[33] P. M. Podsakoff, S. B. MacKenzie, and N. P. Podsakoff, "Sources of method bias in social science research and recommendations on how to control it," Annual Review of Psychology, Review Vol. 63, pp. 539-569, 2012

[34] M. K. Lindell and D. J. Whitney, "Accounting for common method variance in cross-sectional research designs," Journal of Applied Psychology, Article Vol. 86, No. 1, pp. 114-121, 2001

[35] G. Czifra, P. Szabó, M. Míkva, and J. Vaňová, "Lean Principles Application in the Automotive Industry," Acta Polytechnica Hungarica, Vol. 16, No. 5, pp. 43-62, 2019

[36] Z. Nedelko and V. Potočan, "Management practices utilisation in organisations - A comparison between catchingup and well-developed economies," Management (Croatia), Article Vol. 21, pp. 1-20, 2016

[37] A. Bencsik, R. Machová, L. Csókás, T. Juhász, and K. Lazányi, "Survey of Ethical Managerial Behavior - a Three Country Comparative Study," Acta Polytechnica Hungarica, Vol. 15, No. 16, pp. 179-198, 2018

[38] S. Chopra, Supply Chain Management: Strategy, Planning, and Operation. Essex: Pearson Education, 2018

[39] Belas, J., Strnad, Z., Gavurova, B., Cepel, M. (2019) Business Environment Quality Factors Research - SME Management's Platform. Polish Journal of Management Studies, 20(1): 64-77, doi: 10.17512/pjms.2019.20.1.06

[40] Ključnikov, A., Belás, J., Smrčka, L. (2016) Risk-taking and Aggressiveness as the Significant Part of the Entrepreneurial Orientation of SMEs: Case of the Czech Republic. Polish Journal of Management Studies, Volume 14, No. 1, pp. 129-139 